\title{
Pre-Atoka Rocks of Northern Arkansas
}

GEOLOGICAL SURVEY PROFESSIONAL PAPER 314-H

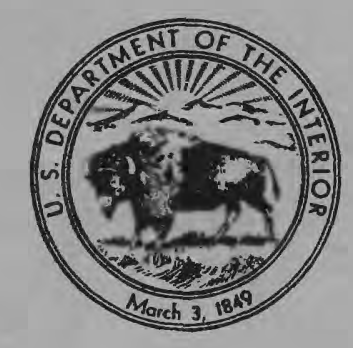




\section{Pre-Atoka Rocks of}

Northern Arkansas

By SHERWOOD E. FREZON and ERNEST E. GLICK

SHORTER CONTRIBUTIONS TO GENERAL GEOLOGY

GEOLOGICAL SURVEY PROFESSIONAL PAPER 314-H

Thickness, lithofacies, and geologic

history of potential oil and gas

producing rocks of Paleozoic age

in northern Arkansas

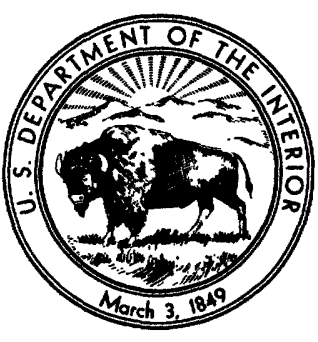

UNITED STATES GOVERNMENT PRINTING OFFICE, WASHINGTON : 1959 


\title{
UNITED STATES DEPARTMENT OF THE INTERIOR
}

\author{
FRED A. SEATON, Secretary
}

GEOLOGIGAL SURVEY

\author{
Thomas B. Nolan, Director
}

\begin{abstract}
The U. S. Geological Survey Library has cataloged this publication as follows:
Frezon, Sherwood Earl, 1921-

Pre-Atoka rocks of northern Arkansas, by Sherwood E. Frezon and Ernest E. Glick. Washington, U. S. Govt. Print. Off., 1959.

iii, 171-189 p. maps, diagrs., table. $30 \mathrm{~cm}$. (U. S. Geological Survey. Professional paper 314-H. Shorter contributions to general geology)

Part of illustrative matter fold. col., in pocket.

Bibliography : p. 186-187.

1. Geology-Árkansas. 2. Rocks, Sedimentary. 3. Geology, Stratigraphic-Paleozoic. I. Glick, Ernest Earwood, 1922- joint author. II. Title. (Series: U. S. Geological Survey. Professional paper 314-H. Series: U. S. Geological Survey. Shorter contributions to general geology)
\end{abstract}

551.7209767

For sale by the Superintendent of Documents, U. S. Government Printing Office Washington 25, D. C. 


\section{CONTENTS}

Abstract

Introduction . . . .

Structural features

Stratigraphy

Precambrian rocks.

Cambrian rocks . . .

Ordovician rocks. .

Pre-Everton rocks . . . .

Everton formation and St. Peter sandstone... -

Post-St. Peter rocks.........

Silurian rocks.

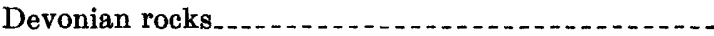

Penters chert....

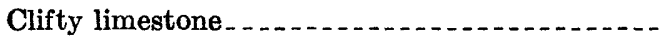

Rocks of Mississippian and Devonian age

Chattanooga shale...

Mississippian rocks . . . . . .

Boone formation

Moorefield formation to Pitkin limestone......
Page

171

171

172

173

173

176

176

176

176

177

177

177

177

178

178

178

179

179

180
Stratigraphy-Continued

Probable latest Mississippian and early Pennsyl-

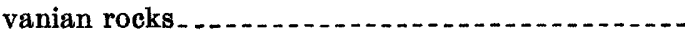

Rocks of the interval between the Pitkin limestone and the Prairie Grove member of the Hale formation (or its apparent equivalent to the south and east of Washington County) -.

Prairie Grove member of the Hale formation in Washington County and its apparent equivalent to the south and east......................

Bloyd shale in Washington County and its apparent equivalent to the south and east.... -

Depositional history

Oil and gas . . . . . . .

Literature cited.................. 186

Index

\section{ILLUSTRATIONS}

[Plates are in pocket]

Plate 20. Structure of the Boone formation and location gas fields producing from rocks of Morrow age.

21. Thickness of the Everton formation and the St. Peter sandstone combined, and percentage distribution of sandstone.

22. Thickness of post-St. Peter rocks of Ordovician age.

23. Thickness of rocks of Silurian age.

24. Areal distribution of pre-Chattanooga rocks, and thickness of the Penters chert.

25. Thickness of the Chattanooga shale exclusive of the basal sandstone member.

26. Thickness of rocks of Mississippian age (Boone to Pitkin) and percentage distribution of limestone.

27. Thickness of the Boone formation and percentage distribution of shale.

28. Thickness of Moorefield-to-Pitkin sequence, and percentage distribution of limestone.

29. Thickness of rocks occupying the interval between the Pitkin limestone (or Fayetteville shale) and the Prairie Grove member of the Hale formation (or its apparent equivalent south and east of Washington County), and percentage distribution of sandstone.

30. Thickness of the Prairie Grove member of the Hale formation in Washington County and of its apparent equivalent south and east of that area, and percentage distribution of limestone.

31. Thickness of the Bloyd shale in Washington County and of its apparent equivalent to the south and east of that area, and percentage distribution of limestone.

FIGURE 37. Index map of Arkansas showing geographic regions and area of accompanying maps

\section{TABLE}

Pre-Atoka formations of northern Arkansas. 


$$
\text { . }
$$




\title{
SHORTER CONTRIBUTIONS TO GENERAL GEOLOGY
}

\section{PRE-ATOKA ROGKS OF NORTHERN ARKANSAS}

\author{
By Sherwood E. Frezon and Ernest E. Glick
}

\begin{abstract}
The part of Arkansas discussed in this report lies north of the Ouachita Mountains and west of the Gulf Coastal Plain and includes parts of the Ozark region and the Arkansas Valley. Pre-Atoka rocks of Ordovician, Sllurian, Devonian, Mississippian, and early Pennsylvanian age crop out in the Ozark region, dip southward under a cover of thick Atoka and younger Pennsylvanian rocks in the Arkansas Valley, and reappear at the surface in the Ouachita Mountain region. Outcrops and wells provide data on the pre-Atoka rocks in the Ozark region and the northern part of the Arkansas Valley; few wells have been drilled in the southern part of the Arkansas Valley and correlations of pre-Atoka rocks between the northern part of the Arkansas Valley and the Ouachita Mountain region cannot be made directly.

The regional structure of pre-Atoka rocks of the Ozark region and the northern part of the Arkansas Valley is reflected by the regional structure of the base of the Boone formation. The regional dip of the base of the Boone formation increases gradually from 10 feet per mile to 200 feet per mile southward across the Ozark region, and steepens to as much as 500 feet per mile along the northern limb of the Arkansas Valley geosyncline.

Thirty-two pre-Atoka formations, ranging from Cambrian to early Pennsylvanian in age, crop out in northern Arkansas and southern Missouri but subsurface data are sufficient to determine the regional thickness and lithofacies of only the Everton formation (Ordovician) and younger rocks. The Everton formation and St. Peter sandstone (Ordovician) combined, a predominantly dolomite and sandstone unit, increases in thickness to the south and east and contains a greater percentage of sandstone to the northwest and northeast. The series of limestone beds and the overlying shale, which makes up the post-St. Peter rocks of Ordovician age, increases in thickness to the southeast but the individual formations of the unit do not change in lithology in the area. Silurian rocks and the Penters chert (Devonian) increase in thickness to the south in the western two-thirds of the area and decrease in thickness to a truncated edge in the southeastern part of the area. The Chattanooga shale increases in thickness southward into the Arkansas Valley and westward in Benton, Washington, and Crawford Countles in the northwestern part of the area. Mississippian rocks, which are composed of limestone, chert, and shale in the north and west, thicken slightly southward in the western half of the area and thickens rapidly to the southeast in the eastern half of the area, where they are represented by more than 2,600 feet of black shale. The
\end{abstract}

thickness of the chert and limestone beds of the Boone formation (Mississippian) decreases to the west and south from the type area in north-central Arkansas, and southeastward the formation grades into black shale. The thickness distribution of Moorefield-to-Pitkin rocks (Mississippian) is similar to that of the total thickness of Mississippian rocks.

The thickness of rocks of Morrow age increases to the south and southeast. The percentage of sandstone in the interval between the Pitkin limestone (or the Fayetteville shale) and the Prairie Grove member of the Hale formation (or its apparent equivalent south and east of Washington County) increases to the northeast and northwest from the south-central part of the area. The percentage of limestone in the Prairie Grove member of the Hale formation and the Bloyd shale of Washington County and of their apparent equivalents south and east of that area decreases to the east and southeast.

The pre-Atoka Paleozoic rocks of northern Arkansas are dominately marine. Pre-Chattanooga rocks, which are dominately marine carbonate sediments, were deposited in relatively shallow, extensive seas. Until the end of St. Peter time, sand was swept intermittently into the area and deposited, but after St. Peter time, Ordovician, Silurian, and Devonian sediments were deposited in seas relatively isolated from sources of coarse clastic sediments. Numerous periods of uplift and erosion interrupted deposition in pre-Chattanooga time and the distribution of the pre-Chattanooga rocks indicates that considerable areal truncation preceded the deposition of both the Penters chert and the Chattanooga shale. Mississippian sandstones, shales, limestones and cherts were deposited on a shelf area in northern and western Arkansas and in a deeper basin to the south and east of the shelf. The dominately clastic preAtoka sediments of Pennsylvanian age were deposited in shallow seas. The area was uplifted and eroded before the deposition of the Atoka formation.

No commercial quantities of oil have been found in northern Arkansas, but commercial quantities of gas have been produced from 5 zones in the pre-Atoka rocks of the area, as well as from several zones in Atoka rocks. It is probable that additional gas will be discovered in pre-Atoka rocks in northern Arkansas. Source beds, reservoir rocks, and geological structures present in the area indicate that oil may be present in small pools in the area.

\section{INTRODUCTION}

This report presents some of the results of stratigraphic investigations begun by the U. S. Geological 
Survey in 1949 to aid in the search for gas and oil in northern Arkansas. Six reports based on these investigations have been published previously (Lantz, 1950; Maher and Lantz, 1952, 1953a and 1953b; Glick and Frezon, 1953; Sheldon, 1954). This report uses both surface and subsurface data to outline the regional thickness, distribution, and lithofacies of Paleozoic rocks older than the Atoka formation (Pennsylvanian) in northern Arkansas.

The area of northern Arkansas discussed in this report (see fig. 37) is bounded on the north by the Missouri State line and on the west by the Oklahoma State line. The eastern and southern limits of the area of this report are delineated by geology: the eastern edge of the area is drawn at the contact of rocks of Paleozoic age and the overlapping Cretaceous and younger rocks present in the Mississippian embayment of the Gulf Coastal Plain, and the southern edge of the area is vaguely delineated by the extent of drilling in the Arkansas Valley. The greater part of the geologic information presented in this report came from twentyone counties of northern Arkansas which encompass an area of approximately 1,200 square miles.

Subsurface data used in this report were obtained from the logs of more than 100 wells drilled in northern Arkansas for gas and oil or water. The logs of 86 of these wells were prepared by the authors and R. J. Lantz, W. A. Chisholm, J. C. Maher, and W. E. Halgarth, of the U. S. Geological Survey, through microscopic examination of well cuttings (see Sheldon, 1954, for most of these logs). The other logs were obtained from oil companies or from publications (Croneis,

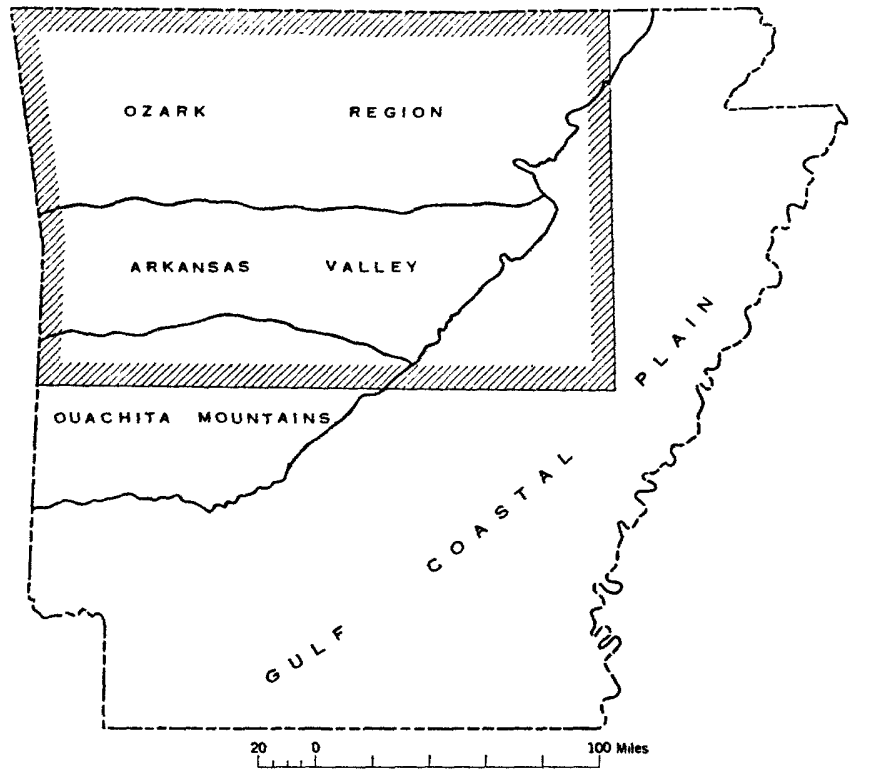

Frourp 37.- Index map of Arkansas showing geographic regions and area of accompanying maps.
1930 ; Lantz, 1950; Breedlove, 1951; Arkansas Geological Survey, 1952; Maher and Lantz, 1952 and 1953b) and interpreted by the authors.

Most of the surface data used in this report were taken from published reports, but some data were obtained in the field by the authors and from unpublished maps of areas in Newton and Searcy Counties. The published reports include detailed geologic maps of Paleozoic rocks in all or parts of Franklin, Crawford, Washington, Benton, Carroll, Madison, Boone, Marion, Baxter, Newton, Searcy, Independence, Izard, and Stone Counties (Adams and Ulrich, 1905; Purdue, 1907; Purdue and Miser, 1916; McKnight, 1935; Miser, 1941; Gordon and Kinney, 1944; Straczek and Kinney, 1950; Maher and Lantz, 1953a) and descriptions of surface sections (Miser, 1922; Giles, 1930; Giles and Brewster, 1930; Easton, 1942; Gordon, 1944; Maher and Lantz, 1952 and 1953a; Glick and Frezon, 1953; and Henbest, 1953). The generalized areas of outcrop of the different pre-Atoka rock units shown on the Geologic Map of Arkansas (Arkansas Geological Survey, 1929) have been used, with minor revisions, in the preparation of the maps in this report.

The authors appreciate the generous assistance of many individuals and organizations interested in the geology of Arkansas. Among these individuals are N. F. Williams, Brun Johnson, J. C. Templeton, R. A. Brant, Howard Clark, D. A. Trumbo, Hampton Halsell, E. L. Clark, J. G. Grohskopf, and Earl McCracken. The following organizations furnished well cuttings and general stratigraphic information: Arkansas Geological and Conservation Commission, Missouri Geological Survey, University of Arkansas, Arkansas-Oklahoma Gas Co., Arkansas-Louisiana Gas Co., Arkansas-Western Gas Co., Cities Service Oil Co., Fort Smith Gas Co., Phillips Petroleum Co., Pure Oil Co., Sinclair Oil and Gas Co., Atlantic Refining Co., Carter Oil Co., Gulf Oil Co., and Lion Oil Co.

\section{STRUCTURAL FEATURES}

The geographic regions shown on the index map (fig. 37) correspond to the areas of the principal structural features of northern Arkansas. The Ozark region is a series of dissected plateaus underlain by slightly undulating beds having a gentle regional dip toward the south; the Arkansas Valley is an easttrending syncline complicated by many large folds and a few important faults; and the Ouachita Mountains region is a structurally complex anticlinorium containing irregular folds and thrust faults of regional extent. Many anticlines, synclines, basins, and faults are present in the area ; in general, the magnitude and complexity of the faults and folds increase southward toward the 
Ouachita Mountains region. The pre-Atoka rocks described in this report dip southward under thick Atoka and younger Pennsylvanian rocks in the Arkansas Valley and reappear at the surface in the Ouachita Mountains region. Cretaceous and younger rocks overlap the Paleozoic rocks in the Gulf Coastal Plain.

The regional structure of northern Arkansas is depicted in plate 20. As indicated on this map, the Boone formation dips generally southward across the Ozark region at rates increasing from about 10 feet per mile at the Missouri State line to about 200 feet or more per mile at the northern edge of the Arkansas Valley. The dip of the Boone in the western half of the area increases abruptly from 200 or 250 feet to approximately 500 feet per mile along the northern limb of the Arkansas Valley syncline. Faults in Crawford, Franklin, Johnson, and Pope Counties probably are responsible in part for the abrupt southward deepening of the Arkansas Valley syncline, but the extent and displacements of the faults have not been fully determined. In the eastern half of the area the southward increase in dip is more gradual. In the deeper part of the syncline the dip of the Boone is unknown. The base of the Boone formation has not been reached in the southern part of the area, even though four wells, in northern Scott, southern Logan, northern Yell, and southern Conway Counties have been drilled to depths of $7,980,4,137,5,632$, and 4,772 feet below sea level respectively.

\section{STRATIGRAPHY}

Pre-Atoka sedimentary rocks in northern Arkansas, which range in age from Late Cambrian to Early Pennsylvanian, have been subdivided into the 32 formations listed in the table. Of these 32 formations, 26 crop out in northern Arkansas; the others, the Lamotte sandstone, Bonneterre dolomite, and the Eminence dolomite, of Late Cambrian age, and the Van Buren formation, Gasconade dolomite, and Roubidoux formation, of Early Ordovician age crop out in adjacent southern Missouri. The pre-Atoka rocks of the Ozark region are approximately 5,000 feet thick and consist mainly of limestone, dolomite, and shale. Equivalent rocks in the Ouachita Mountains region are more than 20,000 feet thick (Arkansas Geological Survey, 1929), and consist mainly of shale and sandstone.

The correlations used in this report are essentially those set up in cross sections previously published as a part of these investigations (Maher and Lantz, 1953b). These cross sections show the striking facies changes that take place in a southeasterly direction. The limestone beds of the Mississippian system and the Morrow group in the Ozark region grade southeastward into shale and sandstone beds that are thought to include equivalents of the Stanley shale (Mississippian and Pennsylvanian) and the overlying Jackfork sandstone (Pennsylvanian) of the Ouachita Mountains region. The reader is referred to these cross sections for details of lithology and correlation.

The distribution, thickness, and lithofacies of preAtoka rocks in northern Arkansas, as known from outcrops and from wells drilled before January 1, 1954, are discussed in the following paragraphs. The areal distribution of pre-Chattanooga rocks, and the thickness and lithofacies of rock units between the base of the Everton formation and the base of the Atoka formation, are illustrated by maps (pls. 21-31). Similar maps for the pre-Everton rocks are not presented because of the relative scarcity of subsurface data for these older rocks. All thicknesses indicated as outcrop thickness on the maps indicate that the unit measured was overlain by a younger unit, thereby eliminating the effect of the present cycle of erosion. The lines of outcrop shown on all maps have been generalized from the Geologic Map of Arkansas (Arkansas Geological Survey, 1929). Inasmuch as the base of the probable latest Mississippian and early Pennsylvanian rocks east of Newton County is not shown on any geologic map, the writers have arbitrarily extended this line to the Gulf Coastal Plain as a limiting line on plate 26 and plates 28-31. This was done with reference to the mapped limits of the Boone and Atoka formations in that area and should involve only slight error at this scale.

\section{PRECAMBRIAN ROCKS}

Precambrian rocks have been penetrated by only five wells, all in the northwestern part of the area, in Madison, Benton, and Washington Counties in the western Ozark region ( $\mathrm{pl} .20$ ). The maximum penetration of Precambrian rocks was recorded in the Independent Oil and Gas Co. No. 1 Banks well, sec. 6, T. 16 N., R. 27 W., Madison County, which was drilled 118 feet into rocks classified as rhyolite by McQueen (Croneis, 1930, p. 193) below a depth of 2,397 feet. The other 4 wells were reported to have been drilled into granitic rocks.

\section{CAMBRIAN ROCKS}

Rocks of Cambrian age have been penetrated by 6 wells in northern Arkansas. Thêse include the 5 wells drilled into Precambrian rocks, and the Camden Oil Co. No. 1 Grissom well, sec. 17 , T. 15 N., R. 31 W., Washington County, which penetrated 57 feet of Cambrian rocks tentatively correlated with the Eminence dolomite. Maher and Lantz (1953b) tentatively assigned a sequence of dolomite beds, 407 feet thick, in the Independent Oil and Gas Co. No. 1 Banks well (sec. 6, T. 16 N., R. 27 W.) to the same formation. The 


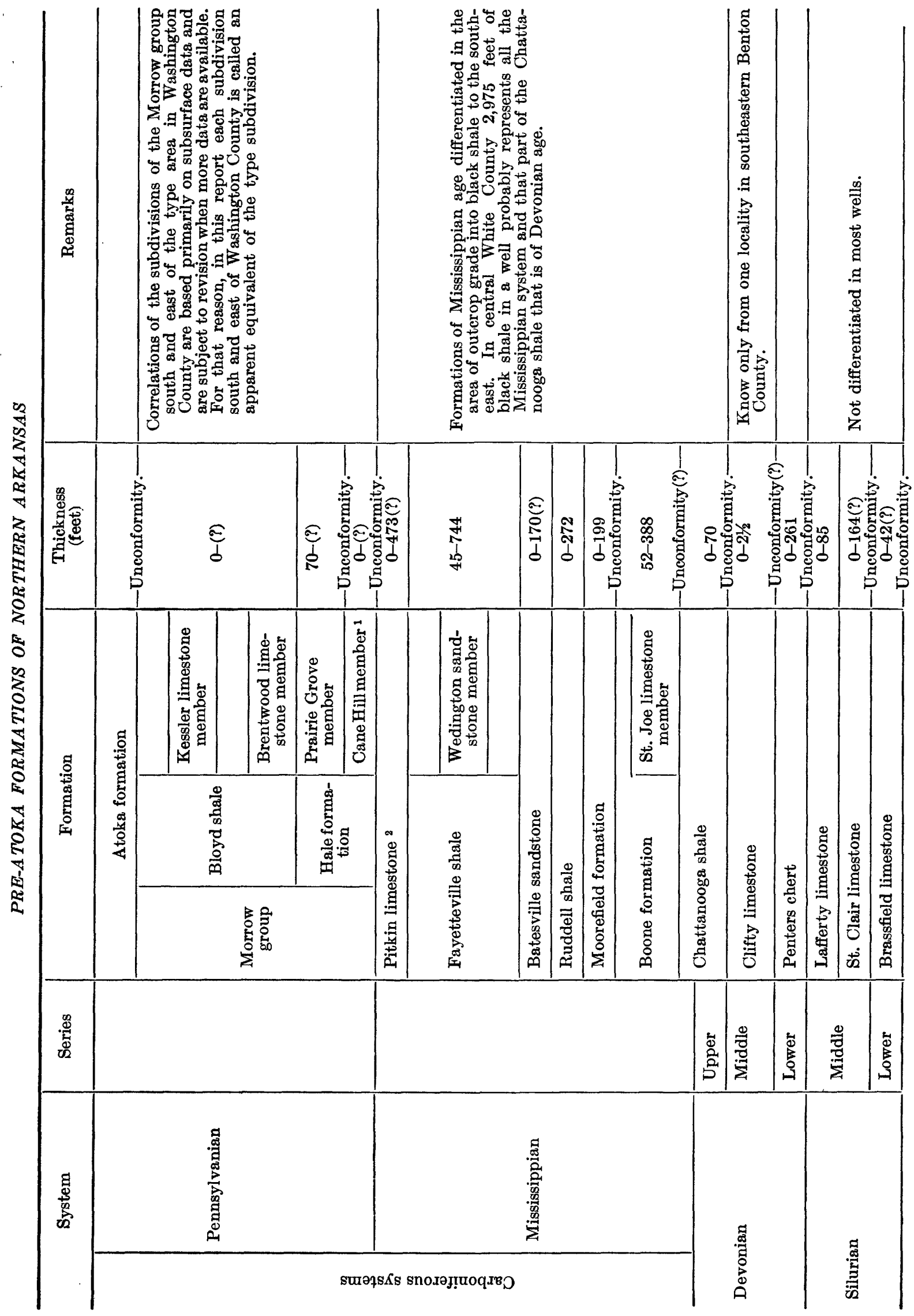




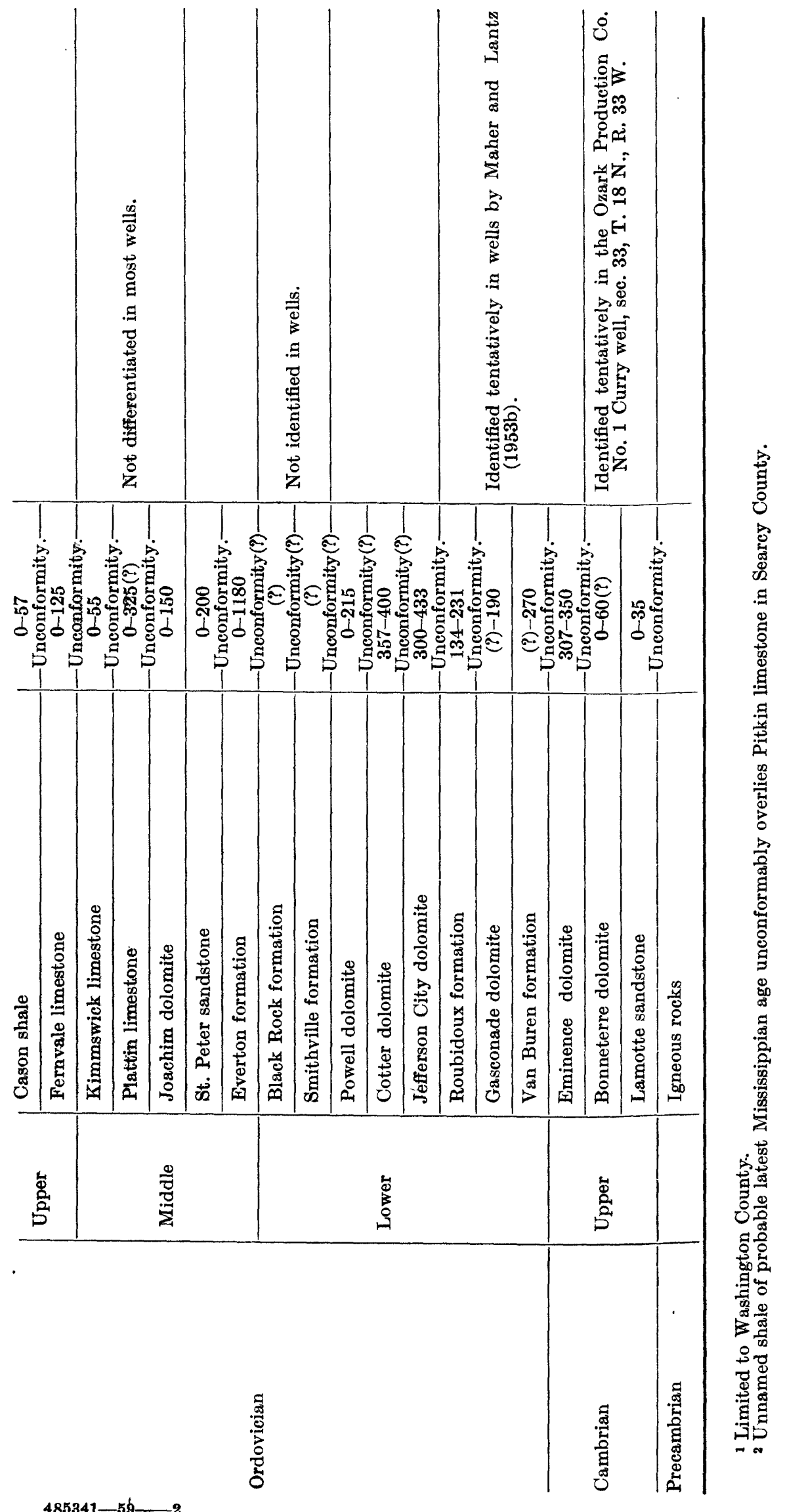


Ozark Production Co. No. 1 E. W. Curry well, sec. 33, T. 18 N., R. 33 W., Benton County, penetrated 445 feet of rocks which have been assigned to the Eminence dolomite, Bonneterre dolomite, and the Lamotte sandstone, all of Cambrian age.

\section{ORDOVICIAN ROCKS}

Although none of the 3 Ordovician formations below the Jefferson City dolomite are exposed in northern Arkansas, they have been penetrated in six wells in Washington, Benton, and Madison Counties of northwestern Arkansas. A thickness of 1,720 feet of Ordovician rocks was penetrated in the Independent Oil and Gas Co. No. 1 Banks well, sec. 6, T. 16 N., R. 27 W., Madison County. The thickness of Ordovician rocks is known to be greater than this figure in White County, where the Deep Rock Oil Co. No. 1 Sample well (sec. 4, T. 10 N., R. 6 W.) was abandoned in the Powell dolomite after drilling into 2,012 feet of Ordovician rocks. The Ordovician rocks are thought to be thicker also in the Gulf Coastal Plain and they are reported to be more than 4,000 feet thick in the Ouachita Mountains region (Geologic Map of Arkansas, 1929). The Ordovician rocks of the Ozark region and the Arkansas Valley are predominantly carbonate rocks and can be conveniently grouped on the basis of gross lithology into three units for regional lithofacies studies: (1) a unit of the preEverton rocks, which is mostly dolomite, (2) a unit of the Everton and St. Peter rocks, which is mostly sandy dolomite and sandstone, and (3) a unit of the post-St. Peter rocks, which is mostly limestone. These units are discussed below.

\section{PRE-EVERTON ROCKS}

The pre-Everton rocks of Ordovician age penetrated in wells in northern Arkansas include, in ascending order, the Van Buren formation, Gasconade dolomite, Roubidoux formation, Jefferson City dolomite, Cotter dolomite, and Powell dolomite (see table). The three lowermost formations- the Van Buren formation, Gasconade dolomite, and Roubidoux formation-are present only in the subsurface. Complete lithologic logs are available for only 3 of the 6 wells which have been drilled through the pre-Everton rocks of Ordovician age in northern Arkansas. These wells and the thickness of the pre-Everton rocks of Ordovician age in them are as follows: Ozark Production Co. No. 1 E. W. Curry, sec. 33, T. 18 N., R. 33 W., Benton County, 1,380 feet; Camden Oil Co. No. 1 J. W. Grissom, sec. 17, T. 15 N., R. 31 W., Washington County, 1,448 feet, Independent Oil Co. No. 1 Banks, sec. 6, T. 16 N., R. 27 W., Madison County, 1,462 feet. Little is known of the complete thickness of pre-Everton rocks in the subsurface in the eastern half of the area, although it is believed that the thickness increases considerably toward the southeast.

\section{DVERTON FORMATION AND ST. PETER SANDSTONE}

Rocks of the Everton formation and St. Peter sandstone are present in the Arkansas Valley and in all but the northernmost part of the Ozark region of Arkansas (pl. 21). The Everton formation, ranging in thickness from a beveled edge to 1,180 feet, crops out nearly continuously from western Carroll County in northwestern Arkansas to the Gulf Coastal Plain. The St. Peter sandstone, ranging in thickness up to 200 feet, crops out in north-central and northeastern Arkansas. The St. Peter has been mapped in discontinuous outcrops from central Newton County eastward to central Izard County, but has not been differentiated from sandstones of the Everton formation east of that point. The Everton formation unconformably overlies the Cotter dolomite or the Powell dolomite, and is unconformably overlain by the St. Peter sandstone except in the northwestern Ozark region, where the Everton is unconformably overlain by younger Ordovician, Devonian, and Mississippian formations. The St. Peter sandstone is apparently conformably overlain by the Joachim dolomite in the eastern third of the region and unconformably overlain by younger Ordovician and Mississippian formations in the western two-thirds.

The known thickness of the unit of combined Everton and St. Peter rocks ranges from a beveled edge in the northern Ozark region to a maximum of 1,338 feet in the Deep Rock Oil Co. No. 1 Sample well, sec. 4, T. 10 N., R. 6 W., in northern White County (pl. 21). In general, the thickness increases southeastward mainly as a result of a considerable thickening of the Everton formation.

The Everton and St. Peter sequence is composed primarily of thick beds of dolomite, sandy dolomite, and sandstone, some lenses of limestone, and a few thin beds of shale. It is less than 25 percent sandstone in parts of Searcy, Stone, Van Buren, Conway, Cleburne, Independence, and White Counties, in the east-central parts of the area, but more than 75 percent sandstone in parts of Washington, Madison, Crawford, and Franklin Counties of northwestern Arkansas (pl. 21). This northwestward increase in amount of sandstone may be due partly to the removal of upper dolomite beds of the Everton by erosion in northwestern Arkansas, but appears to be mainly a result of a northwestward increase in the amount of sand deposited. The percentage of sandstone in the Everton also increases northeastward in Independence and Stone Counties, suggesting that more data from Izard, Fulton, Sharp, Lawrence and Randolph Counties, might show presence of sandy facies similar to those of northwestern Arkansas. 
The distribution, thickness, and lithofacies of the Everton formation suggest that the Everton sea was deeper in the southeastern part of the area, where predominantly carbonate sediments were deposited, than in the northwestern part, where deposition of clastic sediments predominated. The clastic sediments probably were derived from sandstones to the north and accumulated in the shallower areas, where they were rounded and winnowed by wave action. Some of the sand was transported southeastward into the deeper part of the sea, and was included in the carbonate mud being deposited in considerable quantities there. Slight uplift at the close of Everton time permitted the beveling of newly deposited rocks in northern Arkansas. The deeper area to the southeast probably was not brought above sea level and perhaps not up to the depth of wave action. Northern Arkansas was then again submerged, sand was brought in from the north, and a fairly uniform thickness of sandstone (St. Peter sandstone) was deposited over the area. Deposition of sandy carbonate sediments may have continued without interruption during St. Peter time in the deeper part of the basin.

\section{POST-BT. PETER ROCKS}

The post-St. Peter rocks of Ordovician age crop out in central Newton County and eastward discontinuously to the Gulf Coastal Plain near Batesville. They include five formations: in ascending order, the Joachim dolomite, Plattin limestone, Kimmswick limestone, Fernvale limestone, and Cason shale (see table). Each formation has a distinct lithology which simplifies the identification of the formation in the outcrop and in well samples; each is separated from the next overlying formation by an unconformity. The contact of the St. Peter sandstone and the Joachim dolomite is apparently conformable but locally, where the Joachim is absent, the younger Ordovician formations rest unconformably on the St. Peter sandstone. Where the St. Peter is absent, post-St. Peter rocks of Ordovician age rest unconformably on the Everton formation. Post-St. Peter rocks of Ordovician age are unconformably overlain by Silurian, Devonian, or Mississippian rocks.

The recorded thickness of post-St. Peter rocks of Ordovician age ranges from a beveled edge in the subsurface and in the outcrop to 532 feet in the Deep Rock Oil Co. No. 1 Sample well in northern White County. The thickness of post-St. Peter rocks of Ordovician age increases southward in the western half of the area and eastward in the eastern half of the area (see pl. 22).

Each of the five formations of the unit represents a relatively short interval of deposition followed by a brief period of erosion, which resulted in the very ir- regular distribution of each formation. Their lithology suggests that the sediments were deposited on a marine shelf area, and the absence of facies changes within the formations indicates that the environment of deposition was fairly uniform throughout the area. The formations are thinner and more irregularly distributed in the area of outcrop in the Ozark region than they are to the south and southeast, suggesting that the Ozark area may have been covered by a shallower sea during the time of deposition and subjected to more erosion during emergence.

\section{SILURIAN ROCKS}

Rocks of Silurian age are composed of gray to pink, finely to very coarsely crystalline limestone, which has been divided, in ascending order, into the Brassfield limestone, St. Clair limestone, and Lafferty limestone (see table). The Brassfield outcrops are the most restricted in areal extent, being present only in northern Searcy County (McKnight, 1935, p. 58-59; Maher and Lantz, 1953a), and the St. Clair is the most extensive, being present in discontinuous outcrops from eastern Newton County eastward to the Batesville area. Silurian rocks are overlapped by younger rocks west of eastern Newton County. Rocks of Silurian age are present in the subsurface in the southern half of the area from the western border of Arkansas eastward to White and Independence Counties.

The maximum known thickness of Silurian rocks in northern Arkansas is 254 feet (Arkansas-Louisiana Gas Co. No. 1 R. S. Barton well, sec. 27, T. 9 N., R. 28 W., Franklin County). In general, the Silurian rocks are thickest in the western part of the Arkansas Valley, and decrease in thickness to the north and east (pl. 23). They appear to be absent in most of White, southern Cleburne, and eastern Independence Counties.

The limestones of Silurian age were deposited with little, if any, quartz sand on a relatively stable shelf. Slight emergence may have occurred between the deposition of the Brassfield and St. Clair, but otherwise the sea appears merely to have changed in depth during Silurian time. Silurian rocks are apparently absent in the extreme eastern and southeastern parts of the area as a result of pre-Devonian erosion, although the available data for this area are inconclusive.

\section{DEVONIAN ROCKS}

\section{PENTHER CHERT}

Along the outcrop in the Batesville area the Penters chert is composed mainly of light-gray to black chert, interbedded with thin beds or lenses of gray crystalline limestone and dolomite. In the subsurface the forma- 
tion is composed mainly of chert, but west of Pope County it is sandy, ranging from a slightly sandy chert to a cherty sandstone. The sand content does not appear to fit any regular pattern of distribution. The Penters is unconformably overlain by the Chattanooga shale or the Boone formation and unconformably overlies rocks which range in age from Middle Ordovician (Everton formation) to Silurian (Lafferty limestone).

The known thickness of the Penters chert is greatest in Johnson and Pope Counties, in the Arkansas Valley, where it is more than 250 feet (pl. 24). It decreases northward rather regularly to a truncated edge in the southern Ozark region except in Madison and Washington Counties in northwestern Arkansas, and in White and Independence Counties in the eastern part of the area. In southern Madison and eastern Washington Counties, a tongue of Penters chert, less than 40 feet thick but 12 miles wide, extends 15 to 20 miles northwest of the formation limit in adjacent counties and overlies the beveled edges of rocks ranging from Silurian to Everton in age. This northwestward extension represents a remnant of Penters chert preserved when pre-Mississippian erosion removed the formation in adjacent counties. In White and Independence Counties, the Penters decreases abruptly in thickness from 100 feet to a northeasterly-trending truncated edge near the Coastal Plain, which suggests that the Penters was more than 100 feet thick in these counties before uplift and beveling near the end of Devonian time.

\section{CLIFTY LIMESTONE}

The Clifty limestone which crops out at one locality in eastern Benton County (see note on figure 24), was originally described by Purdue and Miser (1916, p. 9). It has not been recognized elsewhere in outcrops or in the subsurface. At the type locality it is $21 / 2$ feet thick and overlies the Everton formation and underlies the Chattanooga shale. It is Middle Devonian (Hamilton) in age and younger than the Penters chert.

\section{ROCKS OF MISSISSIPPIAN AND DEVONIAN AGE}

\section{Chattanooga shaLe}

The Chattanooga shale, as used in this report, refers to the sequence of black carbonaceous fissile shale and thin basal sanstone that occupies the stratigraphic interval between the Penters chert and Boone formation and includes rocks of both Devonian and Mississippian age. It crops out in Stone and Independence Counties in the east and in western Newton, Madison, Carroll, eastern Benton, and eastern Washington Counties, in the northwest, and is present in the subsurface of most of the Arkansas Valley. It is absent from a wide area in north central Arkansas, both at the surface and in the subsurface (pl. 25). In the subsurface of White and Jackson Counties, the Chattanooga shale cannot be differentiated as a unit in the black shale which rests on Devonian or older rocks (see note, pl. 25). The Chattanooga shale is overlain by the Boone formation or rocks of equivalent age and unconformably overlies the Penters chert. It overlaps the beveled edges of successively older formations north or the limits of the Penters chert in Crawford, Madison, Washington, Carroll, Benton, Newton, Stone, and Independence Counties.

The thickness of the Chattanooga shale exclusive of the thin basal sandstone is shown in plate 25. The maximum recorded thickness is 70 feet in Washington and Crawford Counties. The rate of thinning of the black shale ranges from less than 1 foot per mile in much of the area to a maximum to 10 to 15 feet per mile in small areas in Johnson County, and in Stone and Independence Counties.

The contact between the Boone formation and the underlying Chattanooga shale is not the same throughout northern Arkansas. In northwestern Arkansas the Chattanooga shale grades upward into the silty St. Joe limestone member of the Boone formation, and apparently no unconformity separates the two. In the east-central part of the area, on Sylamore Creek in Stone County (sec. 21, T. 15 N., R. 11 W.), the Boone, has a glauconitic and phosphatic sandstone at its base and rests unconformably on the black shale of the Chattanooga. The thin basal sandstone of the Chattanooga, which overlies Silurian rocks, is lithologically different from the sandstone at the base of the Boone. The black shale is not present along the outcrop and in the subsurface in a wide area between Sylamore Creek and northwestern Arkansas.

In the outcrop area in northwestern Arkansas and in the subsurface of most of the Arkansas Valley the Chattanooga shale has a glauconitic and phosphatic basal sandstone. In these areas no sandstone or evidence of unconformity is present between the Chattanooga shale and the Boone formation. Throughout the region where the black shale of the Chattanooga is absent beneath the Boone formation (pl. 25) the Boone is underlain by a persistent glauconitic and phosphatic sandstone usually less than 2 feet thick, which surface mapping (Miser, 1916, p. 9) shows to be the sandstone at the base of the Chattanooga in the outcrops of northwestern Arkansas. This sandstone has been mapped as far east as central Searcy County, about 25 to 30 miles west of the Sylamore Creek locality.

If the sandstone at the base of the Boone on Sylamore Creek correlates with the glauconitic phosphatic sandstone underlying the Boone in Newton and Searcy 
Counties and with the sandstone at the base of the Chattanooga in the northwestern part of the area, the black shale of the Chattanooga beneath the Boone on Sylamore Creek is older than the black shale above the glauconitic phosphatic sandstone in the west. If the sandstones are not correlative, both black shales are approximately equivalent. Additional mapping eastward from central Searcy County to Independence County may solve this problem, and also may determine whether or not the stratigraphic relationship of the Chattanooga and the Boone in the Sylamore Creek section is representative of their relationship throughout the eastern part of the area. In plate 25 all black shale between the Penters chert and the Boone formation is mapped as a single unit.

\section{MISSISSIPPIAN ROCKS}

Rocks of Mississippian age occupying the stratigraphic interval from the base of the Boone formation to the top of the Pitkin limestone crop out in a wide band across the Ozark region of Arkansas and are present in the subsurface of the Arkansas Valley. The rocks in this interval are divided, in ascending order, into the Boone formation, Moorefield formation, Ruddell shale, Batesville sandstone, Fayetteville shale, and Pitkin limestone (see table, p. 174). The thickness of the Boone-to-Pitkin rocks increases from about 400 feet near Fort Smith in the west to more than 2,900 feet in central White County in the east (pl. 26). In some places the basal unit, the Boone formation, or equivalent rocks, rests conformably on the Chattanooga shale; and in other places it rests unconformably on the Chattanooga or on older rocks. In some areas rocks within the interval are unconformably overlain by rocks of probable latest Mississippian age and in other areas by rocks as young as the Prairie Grove member of the Hale formation. The only regional unconformity so far definitely recognized within the interval lies between the Boone formation and post-Boone rocks of Mississippian age.

Boone-to-Pitkin rocks in the northern part of the area are predominantly limestone, cherty limestone, and shale, but locally as much as 20 percent of the section is sandstone. The percentage of limestone within the interval decreases eastward and southward (pl. 26) ; in the vicinity of Fort Smith, 75 to 90 percent of the section is limestone and in central White County less than 5 percent of it is limestone and more than 95 percent is black shale. The limy, slightly sandy facies in the north-central and western part of the area is primarily a shelf deposit; the thick blackshale facies in the southeastern part of the area is a basin deposit. The black-shale facies in central White
County, which is 2,975 feet thick in the Lion Oil Co. No. 1 Nally well, sec. 33 , T. 8 N., R. 7 W., was considered by Maher and Lantz (1953b) to include the equivalent of the Stanley shale, which crops out in the Ouachita Mountain region.

Despite the considerable change in facies across northern Arkansas, the Boone-to-Pitkin rocks are readily separable throughout two-thirds of the area. Therefore the Boone-to-Pitkin rocks are treated in the following discussion in two divisions : the Boone formation and the Moorefield-to-Pitkin sequence.

\section{BOONE FORMATION}

The Boone formation in the area of outcrop is composed of two units; a light-gray to reddish-brown, crinoidal, finely crystalline limestone unit, less than 100 feet thick, the St. Joe limestone member, and an overlying unit, 200 to 350 feet thick, of cherty limestone and interbedded gray dense chert and gray finely crystalline limestone. The contact between the Boone formation and the underlying Chattanooga shale is unconformable in some places and gradational in others (see discussion of Chattanooga shale above). Where the Chattanooga shale is absent, the Boone unconformably overlies Ordovician, Silurian, or Devonian rocks. The top of the formation is marked by a well-defined unconformity in the Ozark region and in the western part of the Arkansas Valley.

The Boone is one of the most extensive formations in northern Arkansas (pl. 27). It crops out over a broad area in 12 northern counties and is represented in the subsurface throughout the Arkansas valley. Its thickness ranges from 50 feet in southern Franklin County to about 375 feet in and around Boone County. Regionally, the thickness of the Boone increases from the southwest, south, and southeast toward Boone County. Local anomalies in thickness are probably the result of post-Boone erosion, which developed an irregular topography on the Boone.

The Boone formation is composed predominantly of limestone and chert in the northern and western parts of the mapped area. In this area the formation contains less than 5 percent shale (pl. 27). This limestone and chert facies grades into limy black shale and black chert to the southeast, in southeastern Van Buren, central Cleburne, and northern White Counties. Farther southeast, in the Lion Oil Co. No. 1 Nally well, sec. 33 , T. 8 N., R. 7 W., central White County, 295 feet of limy black shale in the lower part of a thick black-shale section probably is the equivalent of the Boone plus the equivalent of the Chattanooga shale. The limestone and chert facies was deposited on a relatively stable shelf, approximately in the area in 
which the Boone is less than 5 percent shale (pl. 27). The shale facies was deposited south and east of the shelf in a basin occupying the area in which the Boone is more than 95 percent shale. This area probably extends across the eastern end of the Arkansas Valley into the eastern part of the Ouachita Mountain region and may extend westward to Oklahoma through the central part of the Arkansas Valley. A transitional zone about 20 miles wide, in which the Boone is 5-95 percent shale, lies between the shelf and basin facies.

The decrease in thickness of the Boone formation in the outer part of the limestone area and across the transitional zone and black-shale area may have resulted from a progressively slower rate of deposition away from the central part of the shelf area. However, part of the thinning probably is the result of postBoone Mississippian erosion. In Franklin County thickness lines do not parallel facies lines (pl. 27), and the relationship suggests erosion of the upper part of the Boone which, around the edge of the shelf area, generally is more shaly than the lower part.

\section{MOOREFIELD FORMATION TO PITKIN IIMESTONE}

Moorefield-to-Pitkin rocks form a sequence that crop out across northern Arkansas in an irregular band extending from the Oklahoma State line southwest of Fayetteville eastward to the vicinity of Batesville (pl. 28 ), and are present in the subsurface south of this band. The units of the sequence, in ascending order, are Moorefield formation, dark-gray limy shale and silty limestone; the Ruddell shale, gray fissile clay shale; the Batesville sandstone, silty limy sandstone; the Fayetteville shale, limy black shale; and the Pitkin limestone, shaly limestone (see table). This sequence of conformable units unconformably overlies the Boone formation. It is unconformably overlain either by rocks of probable latest Mississippian age or by rocks as young as the Prairie Grove member of the Hale formation. All or part of the Pitkin limestone and, locally, the upper half of the Fayetteville shale are absent as a result of pre-Hale erosion in the northwest part of the area in Washington, Madison, Carroll, Boone, and Newton Counties and in some sections of the southwest.

Both surface and subsurface data indicate a general southeastward increase in the thickness of the sequence in northern Arkansas (pl. 28). The sequence is less than 200 feet thick at Fort Smith and northward along the Oklahoma State line and is more than 2,600 feet thick in central White County. The Pitkin limestone and part of the Fayetteville shale were removed locally by pre-Hale erosion in the western half of the Ozark region of Arkansas, but elsewhere the sequence probably is nearly complete. The Fayetteville shale and Pitkin limestone form all but 75-100 feet of the sequence except in the Batesville district and in southern Franklin County, where the lowest two formations are locally thick. The thickness of the Moorefield formation and Ruddell shale locally reflects the irregular topography of the eroded Boone surface.

Two sandstone units are present in the Moorefield-toPitkin sequence. The older of these, the Batesville sandstone, has a maximum thickness of about 170 feet (Miser, 1922, p. 40) in the area of outcrop. This formation is commonly represented in wells south of the outcrop by slightly sandy limy shale beds which cannot be readily separated from the underlying Ruddell shale and Moorefield formation. The younger sandstone unit, the Wedington sandstone member of the Fayetteville shale, is present locally in the western half of the area. The Wedington is more than 150 feet thick in western Washington County (Croneis, 1930, p. 68) and about 10 feet thick in northwestern Newton County (Purdue and Miser, 1916, p. 13), but is thin or absent in wells in the southern parts of Crawford, Franklin, and Johnson Counties.

In the southeastern part of the area less than 1 percent of the Moorefield-to-Pitkin sequence is limestone; almost all of the sequence is shale (pl. 28). This shale was deposited in a basin which extended southwestward to the Ouachita Mountain region and temporarily covered all northern Arkansas. The Fayetteville shale of the Ozark region is a basin deposit which accumulated during a northward encroachment of the basin. The basin facies of the sequence interfingers with and grades into a more limy shelf facies in the central, northern, and western parts of the area. The percentage distribution of limestone in the shelf facies is related closely to the distribution of the Pitkin limestone, which locally makes up more than 50 percent of the sequence. In the northwestern part of the area where the Pitkin was removed by pre-Hale erosion, the percentage of limestone is small because the other limestones make up less than 10 percent of the total thickness.

\section{PROBABLE LATEST MISSISSIPPIAN AND EARLY PENNSYLVANIAN ROCKS}

Rocks of the interval from the top of the Pitkin limestone (Mississippian) to the base of the Atoka formation (Pennsylvanian) form a sequence exposed in cliffs and steep slopes across northern Arkansas (pls. 29-31). This sequence of rocks has been mapped as an irregular but continuous outcrop from western Washington County eastward to central Searcy County, but has not been mapped in detail eastward from the latter locality to the Gulf Coastal Plain. This sequence includes all rocks of the Morrow group and any post- 
Pitkin rocks older than Morrow present in northern Arkansas. In the stratigraphic divisions of previous reports the oldest post-Pitkin rocks are not separated from the rocks of Morrow age and, in the opinion of the authors, they are inseparable from the rocks of Morrow age except on the basis of their fauna. The divisions of the Morrow group and their relationships to the oldest post-Pitkin rocks are discussed below.

The sequence ranges in thickness from less than 100 feet, in outcrops in Boone County (Purdue and Miser, 1916 , p. 14), to more than 1,600 feet, in the Lion Oil Co. No. 1 Nally well, sec. 33 , T. 8 N., R. 7 W., in central White County. Well data from Cleburne and northern White Counties indicate the presence of a thick sequence of Morrow rocks in that part of the area and suggest that detailed surface mapping south and west of Batesville may disclose that some of the strata assigned to the overlying Atoka formation on the Geologic Map of Arkansas (1929) are actually a part of the Morrow group.

In its type area in Washington County, Ark., the Morrow group is divided into two formations, the Hale formation and the overlying Bloyd shale. In that area the Hale formation is subdivided into two members, the Cane Hill and the overlying Prairie Grove (Henbest, 1953). Also in Washington County, the Bloyd shale is partially subdivided into members, of which the Brentwood limestone member in the lower part and the Kessler limestone member in the upper part are shown in the table.

In the subsurface south of Washington County the major lithologic facies of the group are similar to those of the Morrow group in its type area and can be correlated as far south as northern Sebastian County with considerable confidence. The same divisions are recognizable along the outcrop as far east as western Newton County.

The major facies of the rocks of Morrow age thicken and change lithologically south and east of western Newton County. However, even there the major divisions of the Morrow group are recognizable if surface and subsurface data are examined carefully. The authors have tentatively correlated and isopached for that part of the area three divisions which they consider to be approximate equivalents of the Cane Hill and Prairie Grove members of the Hale formation and the Bloyd shale (pls. 29-31). Each of these divisions is subject to considerable revision in correlation because few data are available in the area where facies changes are most abrupt.

One of the major unsolved problems in the regional correlation of divisions of the Morrow group concerns the Cane Hill member of the Hale formation. In its type area in Washington County, the Cane Hill unconformably overlies the Pitkin limestone or, where the Pitkin is absent, the Fayetteville shale, both of Mississippian age. 'There the Cane Hill is, by definition, the oldest unit of the Morrow group, but whether it is conformably or unconformably overlain by the Prairie Grove member of the Hale formation remains an open question (Henbest, 1953, p. 1941). The authors believe these two members are separated by the only regional unconformity within the Morrow group. The thickness of the unit made up of rocks younger than the Pitkin and older than the Prairie Grove in Washington County (or its apparent equivalent south and east of Washington County) is shown by isopach lines in plate 29 . The rocks of that unit are considered by the authors to be the Cane Hill member of the Hale formation in Washington County and its probable equivalent south and east of that county. However, a fauna in the lowest 100 feet of the unit in Searcy County is considered by Mackenzie Gordon, Jr., of the U. S. Geological Survey, to be of probable latest Mississippian age. Even though the authors have found no stratigraphic break between these post-Pitkin rocks of probable lastest Mississippian age in Searcy County and the Cane Hill of Washington County, it is possible that two units of shale, one of probable latest Mississippian age and one of early Pennsylvanian age, are mapped together in plate 29 , making the use of the term Cane Hill in the title of that map inadvisable. If two such units of shale are present, the older unit probably is truncated west of central Newton County and the younger unit probably grades into an overlying coarse-grained sandstone unit in about the same area.

\section{ROCKS OF THE INTERVAL BETWEEN THE PITKIN LIME- STONE AND THE PRAIRIE GROVE MEMBER OF THE HALE FORMATION (OR ITS APPARENT EQUIVALENT SOUTH AND EAST OF WASHINGTON COUNTY)}

The rocks in this interval form a unit composed primarily of black micaceous shale, dark-gray siltstone, and fine-grained sandstone (pl. 29); locally there are a few thin fossiliferous limestone beds in the unit. The rocks mapped within this unit include the Cane Hill member of the Hale formation of Washington County, Ark., as well as the previously discussed rocks of probable latest Mississippian age. The unit crops out in southwestern Washington County and eastward to central Searcy County. From Searcy County eastward to the Gulf Coastal Plain it probably is present but has not been studied in detail.

The unit rests unconformably on the Pitkin limestone or, where the Pitkin is absent, on the Fayetteville shale, and is, in the opinion of the authors, unconformably overlain by the Prairie Grove member of the 
Hale formation (or the apparent equivalent of the Prairie Grove south and east of Washington County). The thickness of the unit ranges from a thin edge to more than 700 feet (pl. 29). It is locally thin or absent under the Prairie Grove member in Washington County (Henbest, 1953, p. 1938), or under the apparent equivalent of the Prairie Grove member in west-central Pope County (Maher and Lantz, 1953b), and in Newton and Searcy Counties, where it has been mapped by the authors.

The percentage of sandstone in the unit decreases from more than 50 percent in the vicinity of Fayetteville in the west and in the vicinity of Batesville in the east (pl. 29) to less than 25 percent in the central and southwestern parts of the area, where the unit consists of a basal fine-grained sandstone, 10 to 50 feet thick, and overlying slightly silty black shale beds, 75 to 300 feet thick. In the northwestern part of the area it is composed of silt, silty sandstone, and fine-grained sandstone. The percentage of sandstone in that area is difficult to determine accurately because the bedding is generally shaly or thin and sheety. In the southeast, in eastern Van Buren, Cleburne, and northern White Counties, the unit consists of interbedded fine-grained sandstone and silty shale, but there the individual beds of sandstone are as much as 20 feet thick.

The source of the sediments of the unit is unknown. However, along the outcrop in the western part of Searcy County most of the sandstone is near the base of the unit and locally, pebbles of Pitkin limestone are present in lenses of conglomerate as much as 10 feet above the base of the unit. These lenses of conglomerate are separated from similar basal conglomerate by fine-grained sandstone and shale. In this vicinity the fine sand, some of the silt, and the limestone pebbles of the Pitkin probably came from a source a few miles to the north where Pitkin and older rocks were being eroded. Part of the sand here, as well as most of the sand farther east, is thought to have come from a source east of Batesville, because the amount of sand in the sequence increases in that direction.

The thickness of the unit (shown in plate 29) decreases abruptly near the center of the area in northwestern Pope and in southeastern Newton Counties. This region may have been uplifted slightly and eroded before the deposition of the apparent equivalent of the Prairie Grove member. However, differential erosion in the nature of deep channeling could account for the local decrease in thickness in southeastern Newton County. In outcrops in that region the thickness of the overlying apparent equivalent of the Prairie Grove increases as the thickness of this unit decreases, and little evidence of differential uplift has been noted.
PRAIRIE GROVE MEMBER OF THE HALE FORMATION IN WASHINGTON COUNTY AND ITS APPARENT EQUIVAIENT TO THE SOUTH AND GAST

The Prairie Grove member and its apparent equivalent are composed mainly of sandy limestone and limy sandstone. They form what is probably the most widespread unit of the Morrow group of northern Arkansas (pl. 30), for at no locality are these rocks known to be absent under the protective cover of the Bloyd shale or the Atoka formation. The Prairie Grove member, in the opinion of the authors, unconformably overlies the Cane Hill member of the Hale or, where the Cane Hill is absent, rocks of Mississippian age. The Prairie Grove is overlain conformably by the Bloyd shale or, where the Bloyd was removed by pre-Atoka erosion (pl. 30), unconformably overlain by the Atoka formation.

The recorded thickness of the unit increases from less than 70 feet in the west, in northwestern Newton County and northwestern Sebastian County, to more than 300 feet in the east in central White County (pl. 30 ). The gradual west to east regional thickening of the unit is interrupted by local anomalies in thickness where the unit fills channels in the underlying shale. In southeastern Newton and southwestern Searcy Counties, channels as much as 50 feet deep and 100 yards wide are exposed in cross sections along the outcrop. These channels are filled with coarse-grained sandstone, and quartz-pebble conglomerate.

In the southeast, in central White County and westward to northern Conway County, the unit is predominantly calcareous fine- to medium-grained sandstone. In contrast to the underlying unit of dominantly fine-grained rocks of the apparent equivalent of the Cane Hill, this unit contains scattered grains of very coarse sand and beds of coarse-grained sandstone. Black micaceous shale and siltstone are only minor constituents of the unit. North and west of Conway County the unit becomes increasingly more calcareous, until it grades into sandy oolitic limestone in western Newton, Madison, and Washington Counties. The grain size of the sand in the unit decreases from east to west and southward from the area of outcrop.

Striking features of the outcrops of the Prairie Grove where investigated in the western half of the area are crossbedding, lack of continuity of individual beds, and abundance of clay and quartz pebbles and granules. These features indicate that the rocks were deposited under conditions of strong current or wave action. The basal conglomerate, present locally in the area of outcrop, is the oldest stratum in northern Arkansas known to contain in most localities abundant white quartz granules and pebbles, although a few such pebbles have been found in the oldest post-Pitkin rocks. 
Because the number of quartz pebbles and the amount of coarse sand decrease westward across Searcy and Newton Counties and southward from the area of outcrop, their source is thought to be to the north and east.

The relationship between basin and shelf areas during the deposition of the unit is not apparent. The greater proportion of limestone in Washington and Madison Counties (pl. 30) probably is primarily a reflection of the greater distance of that part of the area from the source of sand. The clastic, crossbedded limestone in those counties was deposited in an environment similar to that farther east where crossbedded, very limy sandstone was deposited. The sea was shallow in the northern part of the area but may have been deeper in the southern and southeastern parts of the area.

The percentage of limestone in east-central Pope County is greater than in the surrounding area (pl. $30)$. This anomaly is based on data from only one well, the Cosden Oil Co. No. 1 Shackleford well, sec. 13, T. $9 \mathrm{~N} ., \mathrm{R} .19 \mathrm{~W}$. In this well, sandy oolitic fossiliferous limestone makes up about 15 percent of the unit, whereas limestone makes up less than 5 percent in the nearest adjoining wells, about 15 miles to the northeast and northwest. However, part of the unit in these wells is very limy sandstone, and this anomaly may therefore represent only a minor change in lithology resulting from a shift of currents or a slight uplift which temporarily decreased the amount of sand entering this area.

\section{BLOYD SHALE IN WASHINGTON COUNTY AND ITS AP- PARENT EQUIVALENT TOWARD THE SOUTH AND EAST}

The Bloyd shale of Washington County and its apparent equivalent south and east of that county form a mappable unit (pl. 31) that crops out in the Ozark region beyond the northern limits of the Atoka formation and as inliers in the Atoka formation in the valleys of many southward flowing streams. In the type area in Washington County, the Bloyd is composed of dark-gray shale, two members of slightly sandy limestone-Brentwood and Kessler limestone members, a minor amount of limy sandstone, and a thin lens of coal.

The Bloyd shale rests conformably on the Prairie Grove member of the Hale formation in the type area and is unconformably overlain by the Atoka formation. The Bloyd or its apparent equivalent increases in thickness from a beveled edge in southern Carroll and northwestern Newton Counties to more than 650 feet in southern Cleburne County (pl. 81). The unit was removed by pre-Atoka erosion in the northwestern part of the area, in parts of Washington, Madison, Newton, Searcy, Carroll, and Boone Counties. Where the unit is present in these counties, its thickness is irregular, as a result of differential erosion. Southward from these counties the effect of the erosion is less pronounced.

The percentage of limestone in the unit decreases from west to east, as the shale and limestone facies typical of the Bloyd shale in the western part of the area grades into a thicker facies of shale and sandstone of the apparent equivalent in the eastern part of the area (pl. 31). Near Fort Smith, 30 to 50 percent of the apparent equivalent is silty oolitic limestone and the rest is dark-gray shale. In the southeast, in White, Cleburne, and parts of Conway, Van Buren, and Pope Counties, less than 5 percent of the apparent equivalent is limestone, and the rest consists of black micaceous shale, dark-gray siltstone, and gray silty slightly limy fine-grained sandstone.

Most of the sediments probably were deposited in a shallow-water environment. Lateral lithologic changes, cross lamination, and the presence of clay pebbles in the sandstone beds are the result of strong current or wave activity. These sandstone beds are separated by sections, as much as 100 feet thick, of darkgray shale which probably were deposited in quiet water. The middle part of the Bloyd is of terrestrial origin in Washington County (Henbest, 1953, p. 194344).

\section{DEPOSITIONAL HISTORY}

During Late Cambrian and Early Ordovician (preEverton) time the Ozark region of Arkansas was a relatively stable marine platform on which predominately carbonate rocks were deposited. At irregular intervals, sand was swept southward across the platform in such quantities that the carbonate material was no longer able to mask the clastic deposits and thin sandstones were deposited over wide areas. Minor oscillations during this deposition caused some of the newly deposited sediments to be eroded for relatively short times before deposition was renewed. During preEverton time the sea in the region of the present day Ouachita Mountains probably was shallow and muddy, and a thick sequence of clastic sediments accumulated as the area subsided. Following the deposition of preEverton rocks, the Ozark region was uplifted and eroded.

At the beginning of Everton time the Ozark region was submerged again-the southeastern part to a greater depth than the rest of the region-and large quantities of sand were brought from the north to mix with carbonate sediments accumulating in the area. Much of the sand was deposited in shallow water in 
the northern and western parts of the area, but some was swept into slightly deeper water in the southeastern part. A minor recession of the sea halted deposition of the Everton formation in the Ozark region, but it is not certain that this interruption extended vary far south. In St. Peter time transgressing seas reworked the newly deposited Everton sands and received new clastic material from the north to form the thick and extensive sandstone of the St. Peter. In the eastern part of the area the carbonate deposits of the Joachim dolomite covered the sandstone before the area was again eroded. After this pre-Plattin erosion the Ordovician seas advanced and retreated across the area between recurrent intervals of gentle warping in the Ozark region. Then regional upwarping followed by erosion marked the close of the Ordovician period.

During Silurian time, the seas advanced over the eroded Ordovician rocks and may have covered most or all the Ozark region. Limestone beds were deposited in a rather stable sand-free environment. The area was uplifted and eroded before the deposition of Devonian rocks. Devonian seas covered the eroded edges of Silurian and older rocks and probably most of northern Arkansas. The Penters chert was the principal deposit of the Devonian seas.

After deposition of Devonian rocks, northern Arkansas was tilted southward and peneplained. During this time the Penters chert was eroded from eastern White and Independence Counties and the Penters and other formations as old as Early Ordovician age were truncated in the Ozark region (pl. 24). A thin basal sandstone with an average thickness about 2 feet was deposited evenly over this peneplained surface by a transgressing sea and was covered by the black shale of the Chattanooga, except in the central and possibly in the eastern parts of the area where Mississippian rocks now rest on the basal sandstone.

During Mississippian time, limestone and some shale of the Boone to Pitkin rocks were deposited on a stableshelf area in northern and western Arkansas and a much thicker sequence of black shale was deposited in a basin south and southeast of the shelf (pl. 26). The basin probably covered much of what is now the central and southern part of the Arkansas Valley and the Ouachita Mountain region. Post-Boone uplifts, which were followed by erosion in the shelf area, probably did not interrupt deposition in the basin.

The depositional history of rocks lying between the top of the Pitkin limestone and the base of the Bloyd shale or its apparent equivalent south and east of Washington County is subject to two different interpretations.

One interpretation may be that after the deposition of the Pitkin limestone and a short period of erosion, the sequence of sandstone, shale, and limestone that make up the rocks of probable latest Mississippian age, was deposited over much of northern Arkansas. Erosion after uplift at the end of the Mississippian period truncated both this sequence and the Pitkin limestone in northwestern Arkansas and cut into the upper part of the underlying Fayetteville shale. During early Morrow time the fine-grained sandstone, dark siltstone and shale of the Cane Hill member of the Hale formation and the overlying series of coarser-grained limy sandstone, sandy limestone, and shale of the Prairie Grove member of the Hale formation were deposited in western and northwestern Arkansas, while a single thicker unit of coarser grained sandstone containing quartz pebbles and shale was deposited to the east and southeast in the stratigraphic interval occupied by the combined Cane Hill and Prairie Grove in the type area. This interpretation is based on the theory that the Pitkin limestone and the rocks of probable latest Mississippian age are separated by a minor unconformity, that the rocks of probable latest Mississippian age and the Hale formation are separated by a significant unconformity, and that the Cane Hill and Prairie Grove members of the Hale formation are separated only locally by an unconformity.

The interpretation favored by the authors is that after the deposition of the Pitkin limestone, northern Arkansas was uplifted and tilted southward. Erosion then truncated the Pitkin limestone and cut into the upper part of the Fayetteville shale in northern and northwestern Arkansas. As the sea readvanced, the fine-grained sandstone, dark siltstone, shale, and limestone that make up rocks of probable latest Mississippian age were deposited in much of northern Arkansas, while Mississippian rocks continued to be eroded farther north and west. As the sea became more widespread, the dark shaly siltstone, silty sandstone, and silty shale of the Cane Hill member of the Hale formation were deposited in the western part of the area, while a thick deposit of fine-grained sandstone and shale accumulated in the central and eastern part. Uplift again caused retreat of the sea from most of the northern part of Arkansas and locally the newly deposited rocks were stripped away. In the Ozark region, deep channels were cut in the relatively soft shale. After this rapid but deep erosion, northern Arkansas was covered by a shallow sea in which pebbles and coarse sand were mixed into a matrix of clastic limestone forming the Prairie Grove member of the Hale formation and its apparent equivalent south and east of Washington County. These coarse clastic sediments probably were derived from the east or northeast. This 
interpretation is based on the theory that the Pitkin limestone and the rocks of probable lastest Mississippian age are separated by a significant unconformity, that the rocks of probable latest Mississippian age and the Cane Hill member of the Hale formation are conformable and are parts of a single transgressive unit, and that the Cane Hill and Prairie Grove members of the Hale formation are separated by a regional unconformity.

Deposition continued until the end of Morrow time without a regional erosional break but with some local erosion and redeposition. The shale, limestone, and lesser amounts of sandstone composing the Bloyd shale were deposited in the western part of the area and the greater thickness of sandstone and shale of its apparent equivalent south and east of Washington County was deposited in the east. After the deposition of these rocks of Morrow age, the area was again tilted southward and eroded.

\section{OIL AND GAS}

Gas fields in the western part of the Arksansas Valley produced about 236 billion cubic feet of sweet dry gas from the time of the first gas discovery in 1902 to the end of 1953 (Dobie, 1953; Arkansas Oil and Gas Commission, 1953). During 1953 , approximately 11.6 billion cubic feet of gas were produced from 200 to 220 wells in 21 fields. Most of this gas came from sandstones of the Atoka formation, which produce in all fields, but some came from rocks of Morrow age in the Clarksville, Cecil, Linville, Ozone, Rudy, White Oak, and Lone Elm fields (pl. 20) and from a sandstone in the Fayetteville shale in the Lone Elm field.

The first discovery of a commercial quantity of gas in rocks of Morrow age was made in the Clarksville field in 1944 (Breedlove, 1951, p. 2-3), when a well was completed in zones of the apparent equivalent of the Bloyd shale that correlate with the Kessler and Brentwood limestone members of the Bloyd shale. The initial potential of this well through perforations at depths of 3,402-3,432 feet and 3,560-3,590 feet was estimated to be 3.5 million cubic feet of gas a day. The initial bottom-hole pressure was 1,420 pounds per square inch. The cumulative production of this well to June 30,1951 was about 1.4 billion cubic feet. The second discovery of gas in rocks of Morrow age was made in the Cecil field in 1949 (Lantz, 1950, p. 1), when a well was completed at a depth of 4,850 to 4,930 feet in the apparent equivalent of the Prairie Grove member of the Hale formation for an estimated potential of 7 million cubic feet a day. The initial bottom-hole pressure was reported to be 1,572 pounds per square inch. This second discovery was followed by the drilling of many wells to test the apparent equivalents of the members of the Hale formation in west-central Arkansas, and, as a result, gas was found in the apparent equivalent of the Prairie Grove member in the White Oak, Lone Elm, Rudy, and Linville fields, and in older post-Pitkin rocks in the Ozone field. The gas in the older postPitkin rocks was found in a sandstone at a depth of 2,347-2,400 feet in the only well completed as of January 1, 1954 in the Ozone field. The potential of the well is estimated to be 1 million cubic feet of gas a day; the bottom-hole pressure is 500 pounds per square inch.

Although small domestic and farm supplies of gas have been obtained for many years from the Boone formation in the vicinity of Fayetteville, the only commercial discoveries in pre-Pennsylvanian rocks have been made since 1953. One well, drilled below the Morrow in the Lone Elm field, found gas in a sandstone in the Fayetteville shale and is reported to be producing several million cubic feet of gas a day from that sandstone. About the same time, gas was discovered in the basal sandstone of the Chattanooga shale at a depth of 566-586 feet in the West Fork field, where three wells are now producing. The first well, in sec. 5, T. 14 N., R. 30 W., was completed for an estimated initial potential of 1.5 million cubic feet of gas a day; the initial pressure was 160 pounds per square inch.

Although no commercial quantities of oil have been discovered in northern Arkansas, geological conditions appear favorable for the accumulation of oil in the area. Anticlinal structures and stratigraphic wedgeouts are abundant; dark bituminous shale and limestone beds of marine origin that might be source beds are well represented; oil seeps and petroliferous odors are not uncommon in the rocks; and, despite the unfavorable opinion gained by the impervious quartzitic nature of the thick Ordovician sandstones at some localities, porous and permeable beds of sandstone, limestone, and dolomite are present and may be potential reservoir rocks for oil. Factors which have retarded prospecting in northern Arkansas include the widespread distribution of fresh water in reservoir rocks, the quartzitic nature of the thick sandstones of Ordovician age, the relative high carbon ratio of coal in the region, and the high cost of drilling through the alternating layers of hard sandstone and soft shale of the Atoka and Morrow rocks.

The pre-Atoka formations that seem most favorable for the accumulation of oil and gas are the apparent equivalents of the members of Hale formation and of the Bloyd shale, both of Morrow age. Although the most important gas fields now producing from rocks of Morrow age are in Tps. 9 and 10 N., the possibilities of finding oil and gas reservoirs are equally favorable or better in the latitude of Tps. 11, 12, and $13 \mathrm{~N}$., where 
these rocks are at shallower depths. The basal postPitkin sandstone in the western half of the area is lenticular and locally is as much as 100 feet thick. Because this sandstone is underlain by the Pitkin limestone and overlain by shale, both of which are possible source rocks, it should not be overlooked as a possible reservoir rock. The apparent equivalent of the Prairie Grove member of the Hale formation is porous and permeable in much of northern Arkansas and probably is the best prospective reservoir rock for oil and gas in the pre-Atoka rocks. The apparent equivalent of the Bloyd shale has good prospects as an oil-and-gasproducing formation throughout the western half of northern Arkansas where rocks that are apparent equivalents of the Brentwood and Kessler limestone members are present, and has fair prospects in the eastern half where some of the sand beds are thick.

The second most favorable reservoir rocks for the accumulation of oil and gas are present in the Moorefield-to-Pitkin rocks of Mississippian age. These include the dark petroliferous oolitic limestone beds of the Moorefield formation, the sandstone and sandy limestone beds of the Batesville sandstone, and the Wedington sandstone member of the Fayetteville shale. An oil seep has been reported in the Batesville sandstone at Batesville (Croneis, 1930, p. 356), and asphaltic residue is present in the basal limestone of this formation about 3 miles northeast of Fayetteville. The possibilities of oil and gas accumulation in the Moorefield formation and Batesville sandstone are thought to be better in the southern Ozark region than in the Arkansas Valley, because these formations are very silty in most of the valley. The Wedington sandstone member of the Fayetteville shale, which produces gas in one well in the Lone Elm field, is present in most of northwestern Arkansas. The widespread areal extent of this lenticular sandstone member of the thick black Fayetteville shale, and the numerous oil and gas shows reported in wells, particularly in Washington and Madison Counties, suggest that additional gas and possibly oil may be found in the Wedington in this area. The presence of light-green oil in limestone concretions in the Fayetteville shale and Pitkin limestone (Croneis, 1930, pp. 76 and 356) is another favorable indication of the petroleum possibilities of the Moorefield-to-Pitkin rocks of Mississippian age.

The Fernvale, Brassfield, and St. Clair limestones and the basal sandstone member of the Chattanooga shale deserve consideration as possible reservoir rocks. The Fernvale, Brassfield, and St. Clair limestones are coarsely crystalline and porous, and, in addition, have been sufficiently beveled by erosion to offer good possibilities for the stratigraphic trapping of oil (pls. 22-
24). The basal sandstone of the Chattanooga produces small quantities of gas in Washington County although it probably is too thin over most of the area to be considered an important drilling objective.

Some of the older Ordovician formations of northern Arkansas contain beds of sandstone, limestone, or dolomite that are possible reservoir rocks for oil and gas, but these formations are not closely associated with rocks that were likely to have been a source of large quantities of oil and gas. The Everton formation and St. Peter sandstone, generally thought to be approximately equivalent to the Simpson group, which produces oil and gas in Oklahoma and Kansas, are usually the deepest objectives in present day drilling in northern Arkansas. A non-commercial show of gas from the St. Peter sandstone was reported in the Deep Rock Oil Co. No. 1 Sample well (sec. 4, T. 10 N., R. 6 W.) in northern White County, and an important oil seep from the Everton formation is present in Marion County. Pre-Everton rocks, generally referred to as the "Arbuckle dolomite" in the midcontinent oil fields, contain fresh water in the northern part of the area. The Town of Marshall water well, in sec. 25, T. $15 \mathrm{~N}$., $16 \mathrm{~W}$., Searcy County, is reported to have found fresh water in the Roubidoux formation at a depth of about 2,200 feet, which is more than 1,000 feet below sea level. Sandstones of the Van Buren and Roubidoux formations appear to have the greatest porosity and permeability of the pre-Everton rocks, but have given no indication of containing oil or gas where tested by drilling.

\section{LITERATURE CITED}

Adams, G. I., and Ulrich, E. O., 1905, Description of the Fayetteville quadrangle (Arkansas-Missouri) : U. S. Geol. Survey Geol. Atlas, Folio 119, 6 p.

Arkansas Geological Survey, 1929, Geologic map of Arkansas. Arkansas Geological Survey, 1952, Arkansas Valley well location map (with accompanying list), compiled and drafted by J. L. McDonnell.

Arkansas Oil and Gas Commission, 1953, Arkansas Oil and Gas statistical Bull., v. 12, nos. 1-12, 1953.

Breedlove, R. L., 1951, Clarksville field, Johnson County, Ark. : Reproduced by the Arkansas Resources and Devel. Comm., Division of Geology, $28 \mathrm{p}$.

Croneis, O. G., 1930, Geology of the Arkansas Paleozoic area, with especial reference to oil and gas possibilities: Arkansas Geol. Survey Bull. 3, 457 p.

Dobie, W. L., 1953, Statistics of oil and gas production ; Arkansas : Petroleum Branch, Am. Ins. Mining and Metallurgical Engineers (covering 1952), v. 7, p. 1-21.

Easton, W. H., 1942, Pitkin limestone of northern Arkansas: Arkansas Geol. Survey Bull. 8, 115 p.

Giles, A. W., 1930, St. Peter and older Ordovician sandstones of northern Arkansas: Arkansas Geol. Survey Bull. 4, $187 \mathrm{p}$. 
Giles, A. W., and Brewster, 1. B., 1930, Hale Mountain section in northwest Arkansas: Am. Assoc. Petroleum Geologists Bull., v. 14, p. 121-138.

Glick, W. E., and Frezon, S. E., 1953, Lithologic character of the St. Peter sandstone and the Everton formation in the Buffalo River valley, Newton County, Ark.: U. S. Geol. Survey Circ. 249, 39 p.

Gordon, Mackenzie, Jr., 1944, Moorefield formation and Ruddle shale, Batesville district, Arkansas: Am. Assoc. Petroleum Geologists Bull., v. 28, p. 1626-1634.

Gordon, Mackenzie, Jr., and Kinney, D. M., 1944, Geologic map. and structure sections of the Batesville district, Independence Co., Arkansas: U. S. Geol. Survey Oil and Gas Inv. Prelim. Map 12.

Henbest, L. G., 1953, Morrow group and lower Atoka formation of Arkansas: Am. Assoc. Petroleum Geologists Bull., v. 37, p. 1935-1953.

Lantz, R. J., 1950, Geological formations penetrated by the Arkansas-Louisiana Gas Company No. 1 Barton well on the Cecil anticline, Franklin County, Arkansas: Arkansas Resources and Development Comm., Division of Geology, Bull. $18,26 \mathrm{p}$.

Maher, J. C., and Lantz, R. J., 1952, Described sections and correlations of Paleozolc rocks at Gilbert, Carver, and Marshall, Arkansas: U. S. Geol. Survey Circ. 160, 19 p.
Maher, J. C., and Lantz, R. J., 1953a, Geology of the Gilbert area, Searcy County, Arkansas: U. S. Geol. Survey Oil and Gas Inv. Map OM 132.

Maher, J. C., and Lantz, R. J., 1953b, Correlation of pre-Atoka rocks in the Arkansas Valley, Arkansas: U. S. Geol. Surrey Oil and Gas Inv. Chart OC 51.

McKnight, E. T., 1935, Zinc and lead deposits of northern Arkansas : U. S. Geol. Survey Bull. 853, 311 p.

Miser, H. D., 1922, Deposits of manganese ore in the Batesville district, Arkansas: U. S. Geol. Survey Bull. 734, 273 p.

Miser, H. D., 1941, Manganese carbonate in the Batesville district, Arkansas: U. S. Geol. Survey Bull. 921-A, p. 1-94.

Purdue, A. H., 1907, Description of the Winslow quadrangle (Arkansas-Indian Territory): U. S. Geol. Survey Geol. Atlas, Folio 154, 6 p.

Purdue, A. H., and Miser, H. D., 1916, Description of the Eureka Springs and Harrison quadrangles (Arkansas-Missouri) : U. S. Geol. Survey Geol. Atlas, Folio 202, 21 p.

Sheldon, M. G., 1954, Sample descriptions and correlations for selected wells in northern Arkansas: Arkansas Resources and Development Comm., Division of Geology, Inf. Circ. 17.

Straczek, J. A., and Kinney, D. M., 1950, Geologic map of the central part of the Batesville manganese district, Independence and Izard Counties, Ark.: U. S. Geol. Survey Mineral Inv. Field Studies Map MF 1. 
. 


\section{INDEX}

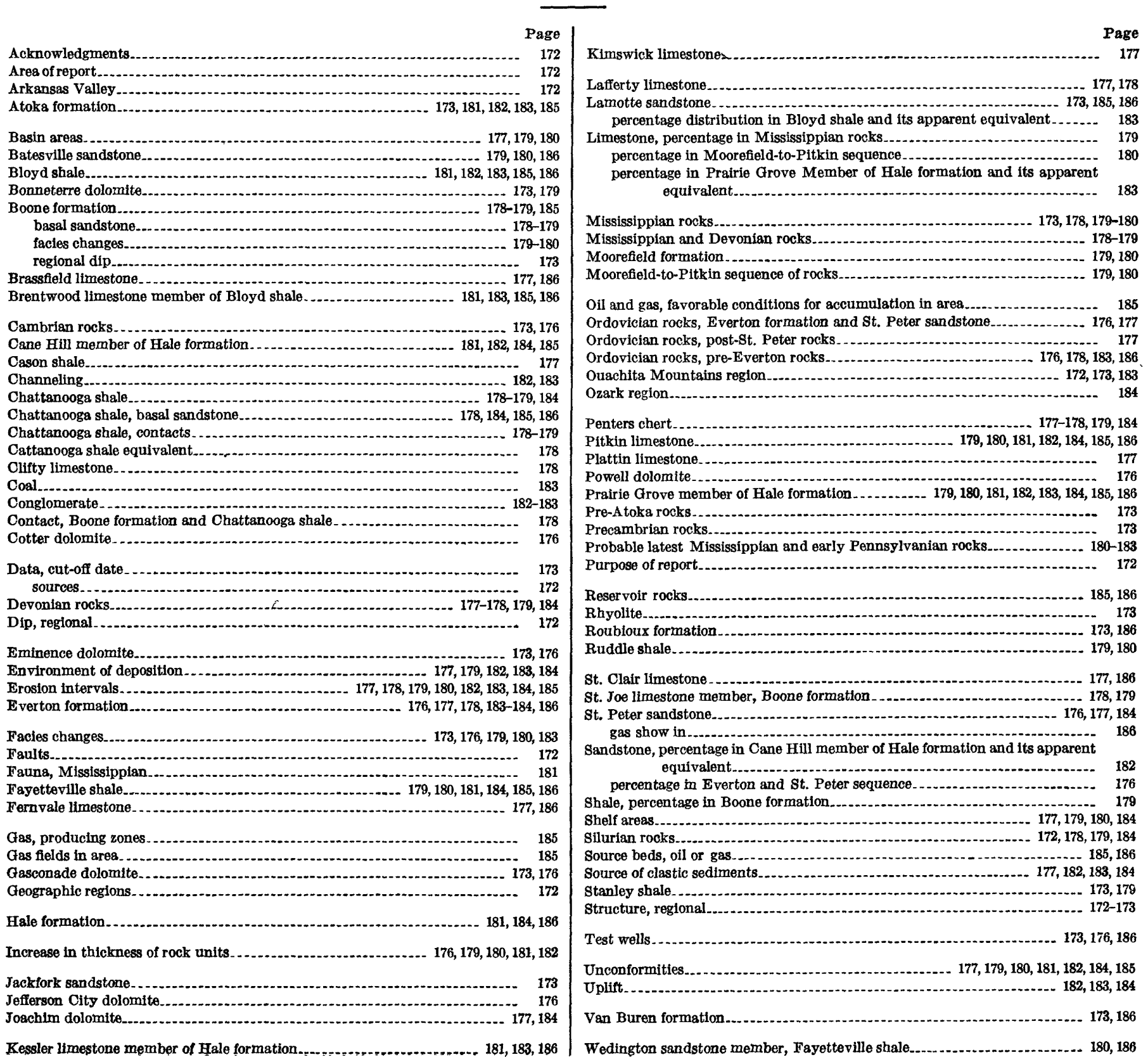




\section{Shorter Contributions}

to General Geology

1957

GEOLOGICAL SURVEY PROFESSIONAL PAPER 314

This Professional Paper was Published

as Separate Chapters, $A-H$

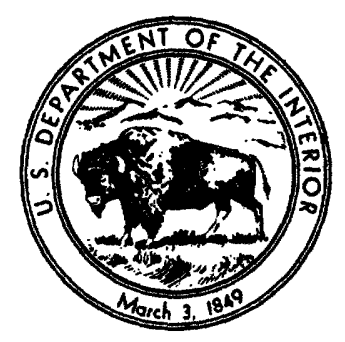

UNITED STATES GOVERNMENT PRINTING OFFICE, WASHINGTON : 1959 


\section{CONTENTS}

[The letters in parentheses are those used to designate the separate chapters]

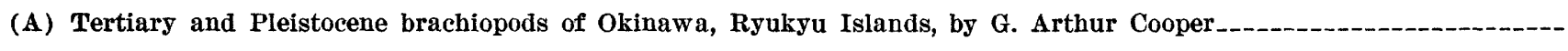

(B) Bathygalea, a genus of moderately deep-water and deep-water Miocene to Recent Cassids, by W. P. Woodring and A. A. Olsson

(C) Stratigraphy of pre-Keeweenawan rocks in parts of northern Michigan, by Harold L. James_........................ 27

(D) Geochemistry of uranium in phosphorite and apatite, by Z. S. Altschuler, R. S. Clarke, Jr., and E. J. Young----- 45

(E) Classification and delineation of nonparallel folds, by John B. Mertie, Jr

(F) Sedimentary studies in the Middle River drainage basin of the Shenandoah Valley of Virginia, by Dorothy Carroll 125

(G) Succession and speciation of the pelecypod Aucella, by Ralph W. Imlay

(H) Pre-Atoka rocks of northern Arkansas, by Sherwood E. Frezon and Ernest E. Glick 